\title{
The Impact of Illicit Drug Use on Spontaneous Hepatitis C Clearance: Experience from a Large Cohort Population Study
}

\author{
Hossein Poustchi, Saeed Esmaili, Ashraf Mohamadkhani, Aghbibi Nikmahzar, Akram Pourshams, \\ Sadaf G. Sepanlou, Shahin Merat, Reza Malekzadeh*
}

Digestive Disease Research Center, Shariati Hospital, Tehran University of Medical Sciences, Tehran, Tehran, Iran

\begin{abstract}
Background and Aims: Acute hepatitis C infection usually ends in chronic infection, while in a minority of patients it is spontaneously cleared. The current population-based study is performed on a large cohort in Golestan province of Iran to examine the demographic correlates of Spontaneous Hepatitis C Clearance.

Methods: Serum samples used in this study had been stored in biorepository of Golestan Cohort Study. These samples were evaluated for anti hepatitis C Virus by third generation Enzyme-linked immunosorbent assay (ELISA). Subjects who tested positive were then invited and tested by Recombinant Immunoblot Assay (RIBA) and Ribonucleic Acid Polymerase Chain Reaction test (PCR). If tested positive for RIBA, subjects were recalled and the two tests were re-done after 6 months. Those subjects who again tested positive for RIBA but negative for PCR were marked as cases of spontaneous clearance.

Results: 49,338 serum samples were evaluated. The prevalence of Chronic Hepatitis C Virus (CHCV) infection based on PCR results was $0.31 \%$. Among those who had acquired hepatitis C, the rate of SC was $38 \%$. In multivariate analysis, illicit drug use both Injecting Use $(\mathrm{OR}=3.271,95 \% \mathrm{Cl}: 1.784-6.000$, p-value $<0.001)$ and Non-Injecting Use $(\mathrm{OR}=1.901,95 \% \mathrm{Cl}: 1.068-$ 3.386, $\mathrm{p}$-value $=0.029$ ) were significant correlates of CHCV infection versus SC.

Conclusions: Illicit drug use whether intravenous or non-intravenous is the only significant correlate of $\mathrm{CHCV}$, for which several underlying mechanisms can be postulated including repeated contacts with hepatitis $C$ antigen.

Citation: Poustchi H, Esmaili S, Mohamadkhani A, Nikmahzar A, Pourshams A, et al. (2011) The Impact of Illicit Drug Use on Spontaneous Hepatitis C Clearance: Experience from a Large Cohort Population Study. PLoS ONE 6(8): e23830. doi:10.1371/journal.pone.0023830

Editor: Paul Proost, University of Leuven, Rega Institute, Belgium

Received February 25, 2011; Accepted July 26, 2011; Published August 24, 2011

Copyright: (c) 2011 Poustchi et al. This is an open-access article distributed under the terms of the Creative Commons Attribution License, which permits unrestricted use, distribution, and reproduction in any medium, provided the original author and source are credited.

Funding: This study was funded by Tehran University of Medical Sciences. The study was not supported by any other internal or external resources. The funders had no role in study design, data collection and analysis, decision to publish, or preparation of the manuscript.

Competing Interests: The authors have declared that no competing interests exist.

*E-mail: malek@ams.ac.ir
\end{abstract}

\section{Introduction}

Hepatitis $\mathrm{C}$ virus (HCV) infection is an important global health problem with estimates of 170 million HCV-infected individuals worldwide [1,2]. Prevalence of hepatitis $\mathrm{G}$ all around the world ranges from $0.02 \%$ to $18 \%$ [3]. In Iran, several studies have been performed on seroprevalence of HCV. Based on a comprehensive systematic review by Alavian et al. [4], the prevalence of $\mathrm{HCV}$ infection among the general population in 6 out of 30 provinces of Iran is $0.16 \%$. Also the estimated seroprevalence of HCV in a more recent population-based study by Merat et al. [5] is around $0.5 \%$, which is concordant with previous studies on blood donors $(0.08 \%-1.3 \%)[6,7]$.

In majority of patients exposed to $\mathrm{HCV}$, the disease becomes chronic, but in a proportion of cases ranging from $14 \%$ to $45 \%$ the virus is spontaneously cleared from the body and the Ribonucleic Acid Polymerase Chain Reaction test (PCR) test becomes negative [8-15].

Several factors have been proposed as correlates of $\mathrm{HCV}$ persistence, including viral and demographic factors, and also route of disease transmission. [8-11,14-19].
Among demographic factors, male gender [19-23], older age $[14,23]$, and ethnic background [12,21,24] are suggested as correlates for $\mathrm{HCV}$ persistence. Host genetic variation is also assumed to explain the heterogeneity in $\mathrm{HCV}$ persistence across individuals because such differences occur even if individuals are exposed to the same HCV strain [18,25,26].

Certain high risk behaviors also increase the risk of $\mathrm{HCV}$ persistence, namely illicit drug use (both Injecting and nonInjecting) $[21,27]$, alcohol consumption $[12,14]$, and unprotected sexual behaviors that lead to co-infection with Human Immunodeficiency Virus (HIV) and Hepatitis B Virus (HBV) [14,28-30]. Still, there are major controversies on the role of these risk factors in various studies.

Along with effective prevention of HBV by universal vaccination in developing countries including Iran, HCV is becoming a more important public health concern replacing HBV [31-33]. There are quite a few studies that report the high rate of HCV coinfection with HBV, HIV, and venereal diseases such as syphilis in Iran [34,35] especially among prisoners [36], which needs immediate attention. Appropriate policy-making in this regard 
necessitates accurate estimation of HCV burden. Distinguishing patients who spontaneously clear HCV from those who develop progressive liver disease and their risk factors is crucial for decision making.

In the current study, we have determined the rate of $\mathrm{HCV}$ spontaneous clearance (SC) and its demographic and host correlates in a large prospective population-based study in Iran.

\section{Results}

All subjects whose serum had tested positive for third generation Enzyme-linked immunosorbent assay (ELISA) were recruited for baseline examination and were recalled after 6 months and no subject was missed in the prospective phase of the study. Three hundred and eighty one (381) subjects tested positive for ELISA, among them, 247 subjects were also positive for Recombinant Immunoblot Assay (RIBA), therefore 134 subjects were labeled as false positive. Chronic HCV infection (CHCV) was confirmed in 152 subjects by PCR and the 95 cases with negative PCR was labeled as SC. During repeat serological testing after 6 months all CHCV subjects remained positive and in none of SC cases did the result of the test change. The HCV seroprevalence in Golestan cohort was $0.5 \%$ based on the result of RIBA, and $0.31 \%$ based on the result of PCR and $38.5 \%$ of infected subjects had spontaneously cleared the infection.

There was no significant difference in the mean age between the 4 groups (CHCV, SC, false positives, and HCV negatives). The frequency of males was significantly higher among subjects with CHCV infection $(73.7 \%)$ and cases of SC (52.6\%) than false positives $(47.0 \%)$ and HCV negatives $(40.0 \%)(\mathrm{p}<0.001)$.

The correlates of HCV acquisition in univariate and multivariate logistic regression were sought. The ultimate correlates in multivariate analysis were: history of blood transfusion, history of imprisonment, family history of hepatitis, cigarette smoking, NonInjecting Drug Use (Non-IDU), and Injecting Drug Use (IDU) (table 1).

The correlates of HCV persistence versus SC were sought. Results of the univariate logistic regression are demonstrated in table 2. Among significant correlates, body piercing appears to be inversely associated with $\mathrm{HCV}$ persistence.

Table 1. Correlates of HCV acquisition in multivariate analysis.

\begin{tabular}{lllll}
\hline Factor & & & & \\
\hline History of blood transfusion & No & 1 & 95\% Cl & P-Value \\
\hline History of imprisonment & Yes & 2.65 & $1.27-5.55$ & 0.010 \\
& No & 1 & & \\
Family history of hepatitis & Nes & 2.01 & $1.02-3.96$ & 0.043 \\
& No & 1 & & \\
Cigarette smoking & Yes & 3.65 & $1.27-10.43$ & 0.016 \\
\hline Non-IDU & Yes & 2.33 & $1.25-4.36$ & 0.008 \\
& No & 1 & & \\
IDU & Yes & 2.09 & $1.16-3.78$ & 0.015 \\
\hline & No & 1 & & \\
\hline
\end{tabular}

Abbreviations: Non-IDU: Non Injecting Drug Use; IDU: Injecting Drug Use. doi:10.1371/journal.pone.0023830.t001
Table 2. Correlates of HCV persistence versus spontaneous clearance in univariate analysis.

\begin{tabular}{|c|c|c|c|c|}
\hline Factor & & OR & $95 \% \mathrm{Cl}$ & P-value \\
\hline \multirow[t]{2}{*}{ Gender } & Female & 1 & & \\
\hline & Male & 2.52 & $1.47-4.33$ & $<0.001$ \\
\hline Age for each 10 years & & 0.81 & $0.61-1.08$ & 0.154 \\
\hline \multirow[t]{2}{*}{ Marital status } & single & 1 & & \\
\hline & married & 3.33 & $2.12-3.57$ & 0.002 \\
\hline \multirow[t]{2}{*}{ Ethnicity } & $\begin{array}{l}\text { Non- } \\
\text { Turkman }\end{array}$ & 1 & & \\
\hline & Turkman & 0.68 & $0.39-1.19$ & 0.184 \\
\hline \multirow[t]{2}{*}{ History of blood transfusion } & No & 1 & & \\
\hline & Yes & 4.18 & $1.81-9.67$ & $<0.001$ \\
\hline \multirow[t]{2}{*}{ History of hospitalization } & No & 1 & & \\
\hline & Yes & 1.23 & $0.74-2.05$ & 0.432 \\
\hline \multirow[t]{2}{*}{ History of surgery } & No & 1 & & \\
\hline & Yes & 0.88 & $0.52-1.49$ & 0.630 \\
\hline \multirow[t]{2}{*}{ History of dentistry } & No & 1 & & \\
\hline & Yes & 1.57 & $0.84-2.92$ & 0.158 \\
\hline \multirow[t]{2}{*}{ History of accident } & No & 1 & & \\
\hline & Yes & 1.67 & $0.84-3.30$ & 0.143 \\
\hline \multirow[t]{2}{*}{ War injury } & No & 1 & & \\
\hline & Yes & 2.49 & $0.80-7.74$ & 0.115 \\
\hline \multirow[t]{2}{*}{ History of imprisonment } & No & 1 & & \\
\hline & Yes & 3.70 & $1.82-7.14$ & $<0.001$ \\
\hline \multirow[t]{2}{*}{ History of tattoing } & No & 1 & & \\
\hline & Yes & 1.70 & $0.44-6.59$ & 0.440 \\
\hline \multirow[t]{2}{*}{ History of traditional phlebotomy } & yNo & 1 & & \\
\hline & Yes & 1.87 & $0.71-4.92$ & 0.206 \\
\hline \multirow[t]{2}{*}{ History of body piercing } & No & 1 & & \\
\hline & Yes & 0.46 & $0.27-0.78$ & 0.004 \\
\hline \multirow[t]{2}{*}{ Family history of hepatitis } & No & 1 & & \\
\hline & Yes & 2.075 & $1.10-3.91$ & 0.024 \\
\hline \multirow[t]{2}{*}{ Cigarette smoking } & No & 1 & & \\
\hline & Yes & 2.048 & $1.19-3.52$ & 0.009 \\
\hline \multirow[t]{2}{*}{ Traditional tobacco smoking } & No & 1 & & \\
\hline & Yes & 2.137 & $1.09-4.18$ & 0.027 \\
\hline \multirow[t]{2}{*}{ Non-IDU } & No & 1 & & \\
\hline & Yes & 2.418 & $1.42-4.13$ & 0.001 \\
\hline \multirow[t]{2}{*}{ Alcohol consumption } & No & 1 & & \\
\hline & Yes & 3.061 & $1.21-7.74$ & 0.018 \\
\hline Body Mass Index & & 1.00 & $0.95-1.05$ & 0.997 \\
\hline \multirow[t]{2}{*}{ IDU } & No & 1 & & \\
\hline & Yes & 14.26 & $7.80-26.07$ & $<0.001$ \\
\hline
\end{tabular}

The test was performed on all 247 patients who had a true positive ELISA test (cases of chronic HCV infection plus cases of spontaneous clearance).

Abbreviations: Non-IDU: Non Injecting Drug Use; IDU: Injecting Drug Use. doi:10.1371/journal.pone.0023830.t002

In the next step, correlates of HCV persistence versus SC were sought using multiple logistic regression. The only variables that remained in the model were $\mathrm{IDU}(\mathrm{OR}=3.271,95 \% \mathrm{CI}: 1.784$ 6.000, p-value $<0.001)$ and Non-IDU $(\mathrm{OR}=1.901,95 \%$ CI: 
$1.068-3.386, \mathrm{p}$-value $=0.029)$. There was no interaction between correlates and confounders.

\section{Discussion}

To the best of our knowledge, the current study is the first that has been conducted in such a large scale on HCV spontaneous clearance in Iran. In this study we were able to demonstrate that $38.5 \%$ of $\mathrm{HCV}$ infected subject might clear $\mathrm{HCV}$ infection spontaneously which is in agreement with many previous studies [8-10,12-14,37]. Also we found that both IDU and non-IDU are the main correlates of CHVG that significantly decrease the chance of $\mathrm{SC}$ among those patients who have acquired $\mathrm{HCV}$ infection.

Over $50 \%$ of the total estimated 170 million HCV cases in the world occur among illicit drug users and over $75 \%$ of incident infections occur in this population [3]. It is known that, illicit drug use is the major correlate of HCV persistence [21,23,37]. Several hypotheses have been suggested to explain the underlying mechanisms of this finding which mainly include: inefficient immunological response [38] which is due to HIV in co-infected subjects $[12,14,39]$ other co-infection or co-morbidities $[40,41]$, and finally repeated -infection [27].

As for IDU, frequent monitoring of $\mathrm{HCV}$ infection status among those who clear a primary infection demonstrated that reinfection of $\mathrm{HCV}$ following control of a primary infection is common [42], with detection of one or more subsequent infections in almost $50 \%$ of cleared subjects [43]. In a study by Aitken and colleagues, re-infection was documented in $46 \%$ of previously cleared IDUs [44]. This data suggests that prior clearance of HCV infection may not provide immunity against re-infection. However it is of interest to know that the rate of self limited infection in subjects who previously cleared the virus is higher than subjects who do not clear the virus after initial infection $[43,45]$. Furthermore, maximum viral load and also duration of viremia in re-infected cases are lower compared to the primary infection [43].

Our results are in discordance with findings of Lewis-Ximenez et al. [46], who found no relationship between illicit drug use or age and rates of SC. The only correlate of $\mathrm{CHCV}$ infection reported by them was low $\mathrm{HCV}$ antibody values [46]. The insignificant results in this study may have been due to the small sample size. Similarly, Santantonio et al. [47] found no demographic factors as correlates of $\mathrm{HCV}$ persistence. The possible explanation is that IDUs in Italy may be less likely to reuse syringes for drug injection.

Our results on the role of Non-IDU in HCV persistence are in accord with previous studies $[21,27,48]$, but there are no agreed upon mechanism for this finding. Some studies imply that nasal inhalation or oral exposure may be plausible routes of transmission probably through shared intranasal canola contaminated with blood [48].

In our study, the seroprevalence of HCV based on RIBA is $0.5 \%$, which is similar to that reported by Merat et al. [5]; however, the seroprevalence of HCV in our results based on PCR is $0.31 \%$ which is again similar to that reported by Alavian et al. [4]. The risk factors that correlate with $\mathrm{HCV}$ acquisition in our study (table 1) are also similar to many previous reports.

In the current study, the rate of SC is significantly higher among females versus males. Also in the univariate logistic regression, male gender is a significant predictor of HCV persistence, and this is supported by previous data $[21,22,49]$. Some previous studies have reported that the rate of $\mathrm{SC}$ is higher among females. The apparently higher rate of $\mathrm{HCV} \mathrm{SC}$ in females is postulated to be due to effect of sex hormone [50] or attributed to genetic and immunological differences between males and females. In our study, gender was not found to be a significant correlate of $\mathrm{HCV}$ persistence in multivariate logistic regression analysis. The main reason for this finding may be the fact that IDU is more common among males. This finding implies that the inherent attributes of female gender have probably no direct effect on the natural history of CHCV which is discordant with previous studies $[20,22,25,49,51]$. With a similar justification, the seemingly protective role of body piercing in $\mathrm{HCV}$ persistence is due to the fact that in our study, women added up to $95.4 \%$ of subjects who had pierced while the percentage declined to $1.3 \%$ among those who had not, which shows that body piercing is associated with gender and thus is a confounder.

Since the Golestan Cohort Study (GCS) is an aged cohort and the median age of our subjects was 54 years, re-infection might have happened several times and seroconversion might have happened at unknown time; therefore, our cohort may represent a selection of subjects who have recovered from multiple bouts of $\mathrm{HCV}$ infections. Studies in older $\mathrm{HCV}$ infected subjects documented that prior clearance of $\mathrm{HCV}$ decreases the rate of persistent re-infection compared to initial infection [29,45]; therefore, the duration of re-infection in subjects who have cleared multiple infections may be progressively shorter with each reinfection and this may have been the case in our study too but longer follow up is required to document this claim.

Lastly we compared the rate of SC in Turkmens versus nonTurkmens and in Turkmens versus immigrants from the southern province of Sistan and Balouchestan, who are the second major ethnic group residing in Golestan. Contrary to other studies, we did not find significant difference in the rate of SC between different ethnic groups residing in the province of Golestan. $[12,21,24]$.

The main strengths of our study are the prospective populationbased design and the large sample size which have been tested. The main limitation is the absence of young subjects in study population. Other limitation includes absence of HCV genotype data.

In conclusion this study revealed a $38.5 \%$ spontaneous clearance rate among $\mathrm{HCV}$ infected subjects in Golestan. We were able to demonstrate that illicit drug use, either Injecting or non-Injecting, are the main correlates of HCV persistence in Golestan province. Harm reduction interventions including distribution of sterile syringes among IDUs, can be an effective

Table 3. The demographic characteristics of GCS subjects $(\mathrm{N}=49,338)$ whose serum were available for HCV testing.

\begin{tabular}{lll}
\hline Variable & & \\
\hline Gender & Female & Number (\%) \\
\hline Age & Male & $28,397(57.6)$ \\
& $40-45$ years & $20,941(42.4)$ \\
& $46-55$ years & $14,061(28.5)$ \\
Place of Residence & Urban years & $19,735(40.0)$ \\
& Rural & $15,542(31.5)$ \\
Ethinicty & Turkmen & $9,868(20.0)$ \\
& Non-Turkmen & $39,470(80.0)$ \\
\hline
\end{tabular}

Abbreviations: GCS: Golestan Cohort Study; HCV: Hepatitis C Virus. doi:10.1371/journal.pone.0023830.t003 


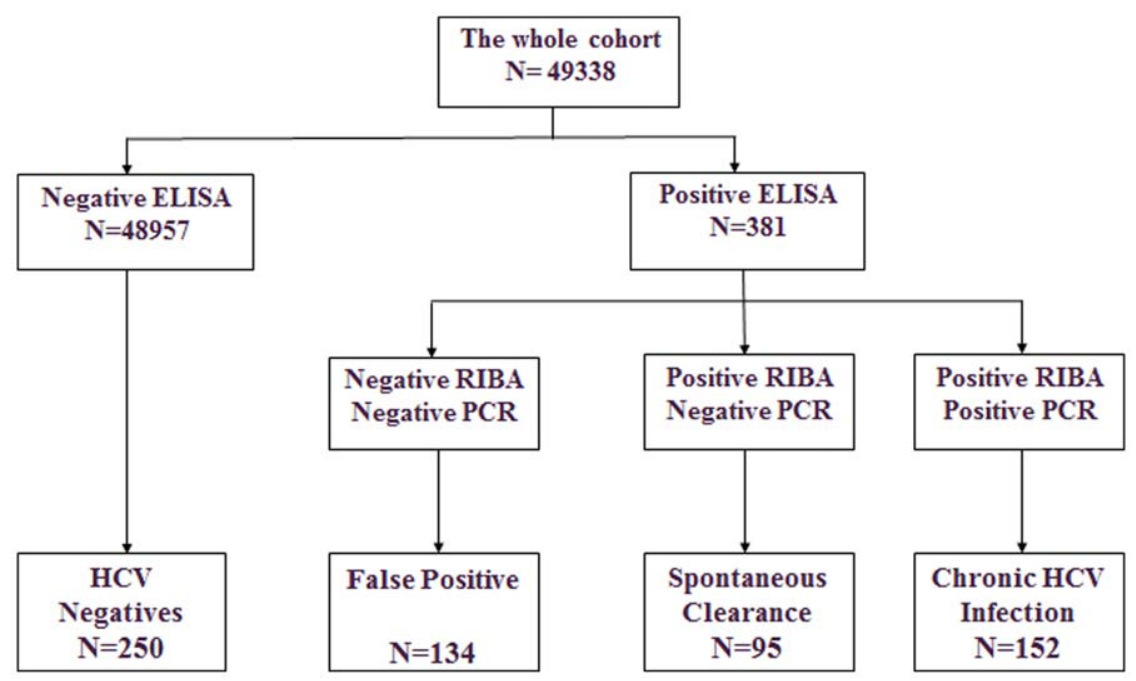

Figure 1. Classification of subjects into cases of chronic HCV infection, Spontaneous Clearance, false positives and HCV negatives. doi:10.1371/journal.pone.0023830.g001

strategy to prevent $\mathrm{HCV}$ infection and re-infection in this population, which may play an important role in reducing the burden of $\mathrm{HCV}$ infection in Iran. Further studies which include younger age populations are necessary in future.

\section{Materials and Methods}

The study was approved by the ethics committee of Digestive Disease Research Center, Tehran University of Medical Sciences. Written informed consent was obtained from all participants. To determine the rate of $\mathrm{HCV} \mathrm{SC}$, we used serum samples stored in biorepository of GCS. The details of GCS have been reported elsewhere [52]. In short, GCS was originally designed to investigate the burden and etiology of upper gastro-intestinal cancers in Northeast of Iran. A total of 50,045 subjects aged 40-75 have been recruited from 3 main districts of the Golestan province in southeast of the Caspian Sea and have been followed-up for 7 years. Subjects have been selected by multi-stage systematic cluster random sampling. Tissue samples including blood, hair, and nail have been collected and stored. The demographic characteristics of the GCS subjects are demonstrated in table 3 .

For the purpose of the current study, stored serum samples of 49,338 subjects were available for HCV study by ELISA (Diapro, Italy). Positive subjects were contacted via telephone and invited to refer for fresh blood sample collection. Invited subjects who did not respond or were not able to come but did consent to participate in study were visited at home and their blood sample was taken. Samples were transferred in $+4^{\circ} \mathrm{C}$ temperature which took less than 4 hours from collection site to $-80^{\circ} \mathrm{C}$ freezers. No subject was missed.

The newly collected fresh blood samples were tested by ELISA again. All ELISA positive subjects were then tested by Recombinant Immunoblot Assay (RIBA) (MT Company, Germany). RIBA negative subjects were labeled as False Positives. RIBA positive subjects were further tested by Ribonucleic Acid Polymerase Chain Reaction (PCR) (STRPTM Hepatitis C Virus Detection Kit from Cinna Gen- Iran). To test blood samples by PCR, an unthawed sample was used for QubasTaqman with detection limit of 50 copy number.

\section{References}

1. Centers for Disease Control and Prevention (1998) Recommendations for prevention and control of hepatitis $\mathrm{C}$ virus (HCV) infection and HCV-related chronic disease MMWR Recomm. Rep 47: 1-39.
Six months later, we again performed both RIBA and PCR on subjects who had tested positive for RIBA in the first session. RIBA and PCR positive subjects were classified as cases of chronic HCV infection and RIBA positive but PCR negative subjects were labeled as cases of SC. Control subjects were randomly selected from the bio-repository of the whole cohort (Figure 1).

Demographic data for all subjects were extracted from the GCS database. Data on history of exposure were similarly extracted from the database for HCV negatives. All HCV positive subjects were questioned again about risk factors at the time blood sample was collected.

All analyses were carried out using the statistical software package SPSS for Windows version 18 (Chicago: SPSS Inc., USA). Continuous variables are summarized as mean \pm standard deviation of the mean (SD) and categorical variables as frequency and percentage unless otherwise stated. Logistic regression models were used to investigate correlates of $\mathrm{HCV}$ acquisition and $\mathrm{HCV}$ persistence. The selected multivariate model was backward Wald in which, variables that were significant in univariate model were included. P-values less than 0.05 were considered statistically significant.

\section{Acknowledgments}

Many individuals have contributed to this study. We wish to thank the study participants for their cooperation over many years and the Behvarz working in the study areas for their help. We also would like to express our special thanks to Golestan Cohort lab technicians. We received special support from the Social Security Organization of Iran Golestan Branch. We also enjoyed the close collaboration of Golestan health deputies and the Chief of the Gonbad health district.

\section{Author Contributions}

Conceived and designed the experiments: HP SE AP. Performed the experiments: AM AN. Analyzed the data: HP SGS. Contributed reagents/ materials/analysis tools: HP SE AM. Wrote the paper: HP SE SGS SM RM. Supervised the study: AP RM.

2. WHO Consultation Report (1999) Global surveillance and control of hepatitis C. Report of a WHO Consultation organized in collaboration with the Viral Hepatitis Prevention Board, Antwerp, Belgium. J Viral Hepat 6: 35-47. 
3. Shepard CW, Finelli L, Alter MJ (2005) Global epidemiology of hepatitis C virus infection. Lancet Infect Dis 5: 558-567.

4. Alavian SM, Ahmadzad-Asl M, Lankarani KB, Shahbabaie MA, BahramiAhmadi A, et al. (2009) Hepatitis C infection in the general population of Iran: A systematic review. Hep Mon 9: 211-223.

5. Merat S, Rezvan H, Nouraie M, Jafari E, Abolghasemi H, et al. (2010) Seroprevalence of hepatitis $\mathrm{C}$ virus: the first population-based study from Iran. Int J Infect Dis 14 Suppl 3: e113-116.

6. Javadzadeh-Shahshahani H (2007) Comparison of the positive predictive value of two enzyme immunoassay screening kits for hepatitis $\mathrm{C}$ in blood donors. Sci J Iranian Blood Transfus Org Res Cent 4: 51-57.

7. Kafi-abad SA, Rezvan H, Abolghasemi H, Talebian A (2009) Prevalence and trends of human immunodeficiency virus, hepatitis $\mathrm{B}$ virus, and hepatitis $\mathrm{C}$ virus among blood donors in Iran, 2004 through 2007. Transfusion 49: 2214-2220.

8. Gerlach JT, Diepolder HM, Zachoval R, Gruener NH, Jung MC, et al. (2003) Acute hepatitis $\mathrm{C}$ : high rate of both spontaneous and treatment-induced viral clearance. Gastroenterology 125: 80-88.

9. Kamal SM (2008) Acute hepatitis C: a systematic review. Am J Gastroenterol 103: 12831297. quiz 1298.

10. Kondili LA, Chionne P, Costantino A, Villano U, Lo Noce C, et al. (2002) Infection rate and spontaneous seroreversion of anti-hepatitis $\mathrm{C}$ virus during the natural course of hepatitis $\mathrm{C}$ virus infection in the general population. Gut 50: 693-696.

11. Mazzeo G, Azzaroli F, Giovanelli S, Dormi A, Festi D, et al. (2003) Ten year incidence of $\mathrm{HCV}$ infection in northern Italy and frequency of spontaneous viral clearance. Gut 52: 1030-1034.

12. Piasecki BA, Lewis JD, Reddy KR, Bellamy SL, Porter SB, et al. (2004) Influence of alcohol use, race, and viral coinfections on spontaneous $\mathrm{HCV}$ clearance in a US veteran population. Hepatology 40: 892-899.

13. Santantonio T, Sinisi E, Guastadisegni A, Casalino C, Mazzola M, et al. (2003) Natural course of acute hepatitis C: a long-term prospective study. Dig Liver Dis 35: 104-113.

14. Thomas DL, Astemborski J, Rai RM, Anania FA, Schaeffer M, et al. (2000) The natural history of hepatitis $\mathrm{C}$ virus infection: host, viral, and environmental factors. JAMA 284: 450-456.

15. Villano SA, Vlahov D, Nelson KE, Cohn S, Thomas DL (1999) Persistence of viremia and the importance of long-term follow-up after acute hepatitis C infection. Hepatology 29: 908-914.

16. Blackard JT, Shata MT, Shire NJ, Sherman KE (2008) Acute hepatitis C virus infection: a chronic problem. Hepatology 47: 321-331.

17. Maheshwari A, Ray S, Thuluvath PJ (2008) Acute hepatitis C. Lancet 372: 321-332.

18. Singh R, Kaul R, Kaul A, Khan K (2007) A comparative review of HLA associations with hepatitis $\mathrm{B}$ and $\mathrm{C}$ viral infections across global populations. World J Gastroenterol 13: 1770-1787.

19. Wang CG, Krantz E, Klarquist J, Krows M, McBride L, et al. (2007) Acute hepatitis $\mathrm{C}$ in a contemporary US cohort: modes of acquisition and factors influencing viral clearance. J Infect Dis 196: 1474-1482.

20. Bakr I, Rekacewicz C, El Hosseiny M, Ismail S, El Daly M, et al. (2006) Higher clearance of hepatitis $\mathrm{C}$ virus infection in females compared with males. Gut 55: 1183-1187.

21. Grebely J, Raffa JD, Lai C, Krajden M, Conway B, et al. (2007) Factors associated with spontaneous clearance of hepatitis $\mathrm{C}$ virus among illicit drug users. Can J Gastroenterol 21: 447-451.

22. Kenny-Walsh E (1999) Clinical outcomes after hepatitis C infection from contaminated anti-D immune globulin. Irish Hepatology Research Group. N Engl J Med 340: 1228-1233.

23. Wietzke-Braun P, Manhardt LB, Rosenberger A, Uy A, Ramadori G, et al. (2007) Spontaneous elimination of hepatitis C virus infection: a retrospective study on demographic, clinical, and serological correlates. World J Gastroenterol 13: 4224-4229.

24. Aborsangaya KB, Dembinski I, Khatkar S, Alphonse MP, Nickerson P, et al. (2007) Impact of aboriginal ethnicity on HCV core-induced IL-10 synthesis: interaction with IL-10 gene polymorphisms. Hepatology 45: 623-630.

25. Alric L, Fort M, Izopet J, Vinel JP, Bureau C, et al. (2000) Study of host- and virus-related factors associated with spontaneous hepatitis $\mathrm{C}$ virus clearance. Tissue Antigens 56: 154-158.

26. Thomas DL, Thio GL, Martin MP, Qi Y, Ge D, et al. (2009) Genetic variation in IL28B and spontaneous clearance of hepatitis C virus. Nature 461: 798-801.

27. Page K, Hahn JA, Evans J, Shiboski S, Lum P, et al. (2009) Acute hepatitis C virus infection in young adult injection drug users: a prospective study of incident infection, resolution, and reinfection. J Infect Dis 200: 1216-1226.
28. Alter MJ (2006) Epidemiology of viral hepatitis and HIV co-infection. J Hepatol 44: S6-9.

29. Mehta SH, Cox A, Hoover DR, Wang XH, Mao O, et al. (2002) Protection against persistence of hepatitis C. Lancet 359: 1478-1483.

30. Shores NJ, Maida I, Soriano V, Nunez M (2008) Sexual transmission is associated with spontaneous HCV clearance in HIV-infected patients. J Hepatol 49: 323-328.

31. Alavian SM, Adibi P, Zali M-R (2005) Hepatitis C virus in Iran: epidemiology of an emerging infection. Arch Iran Med 8: 84-90.

32. Jabbari A, Besharat S, Khodabakhshi B (2008) Hepatitis C in hemodialysis centers of Golestan province, northeast of Iran (2005). Hep Mon 8: 61-65.

33. Merat S, Rezvan H, Nouraie M, Jamali A, Assari S, et al. (2009) The prevalence of hepatitis B surface antigen and anti-hepatitis B core antibody in Iran: a population-based study. Arch Iran Med 12: 225-231.

34. Vahdani P, Hosseini-Moghaddam S, Family A, Moheb-Dezfouli R (2009) Prevalence of HBV, HCV, HIV, and syphilis among homeless subjects older than fifteen years in Tehran. Arch Iran Med 12: 483-487.

35. Vahdani P, Hosseini-Moghaddam S, Gachkar L, Sharifi K (2006) Prevalence of hepatitis $\mathrm{B}$, hepatitis $\mathrm{C}$, human immunodeficiency virus, and syphilis among street children residing in southern Tehran, Iran. Arch Iran Med 9: 153-155.

36. Zakizad M, Salmeh F, Yaghoobi T, Yaghoubian M, Nesami MB, et al. (2009) Seroprevalence of hepatitis $\mathrm{C}$ infection and associated risk factors among addicted prisoners in Sari-Iran. Pak J Biol Sci 12: 1012-1018.

37. Cox AL, Netski DM, Mosbruger T, Sherman SG, Strathdee S, et al. (2005) Prospective evaluation of community-acquired acute-phase hepatitis $\mathrm{C}$ virus infection. Clin Infect Dis 40: 951-958.

38. Chung RT (2005) Acute hepatitis C virus infection. Clin Infect Dis 41 Suppl 1: S14-17.

39. Messick K, Sanders JC, Goedert JJ, Eyster ME (2001) Hepatitis C viral clearance and antibody reactivity patterns in persons with haemophilia and other congenital bleeding disorders. Haemophilia 7: 568-574.

40. Barrett S, Goh J, Coughlan B, Ryan E, Stewart S, et al. (2001) The natural course of hepatitis $\mathrm{C}$ virus infection after 22 years in a unique homogenous cohort: spontaneous viral clearance and chronic HCV infection. Gut 49: 423-430.

41. Mirmomen S, Alavian SM, Hajarizadeh B, Kafaee J, Yektaparast B, et al. (2006) Epidemiology of hepatitis $\mathrm{B}$, hepatitis $\mathrm{C}$, and human immunodeficiency virus infecions in patients with beta-thalassemia in Iran: a multicenter study. Arch Iran Med 9: 319-323.

42. Pham ST, Bull RA, Bennett JM, Rawlinson WD, Dore GJ, et al. (2010) Frequent multiple hepatitis $\mathrm{C}$ virus infections among injection drug users in a prison setting. Hepatology 52: 1564-1572.

43. Osburn WO, Fisher BE, Dowd KA, Urban G, Liu L, et al. (2010) Spontaneous control of primary hepatitis $\mathrm{C}$ virus infection and immunity against persistent reinfection. Gastroenterology 138: 315-324.

44. Aitken CK, Lewis J, Tracy SL, Spelman T, Bowden DS, et al. (2008) High incidence of hepatitis $\mathrm{C}$ virus reinfection in a cohort of injecting drug users. Hepatology 48: 1746-1752.

45. Grebely J, Conway B, Raffa JD, Lai C, Krajden M, et al. (2006) Hepatitis C virus reinfection in injection drug users. Hepatology 44: 1139-1145.

46. Lewis-Ximenez LL, Lauer GM, Schulze Zur Wiesch J, de Sousa PS, Ginuino CF, et al. (2010) Prospective follow-up of patients with acute hepatitis $\mathrm{C}$ virus infection in Brazil. Clin Infect Dis 50: 1222-1230.

47. Santantonio T, Medda E, Ferrari C, Fabris P, Cariti G, et al. (2006) Risk factors and outcome among a large patient cohort with community-acquired acute hepatitis C in Italy. Clin Infect Dis 43: 1154-1159.

48. Santana Rodriguez OE, Male Gil ML, HernandezSantana JF, Liminana Canal JM, Martin Sanchez AM (1998) Prevalence of serologic markers of HBV, HDV, HCV and HIV in non-injection drug users compared to injection drug users in Gran Canaria, Spain. Eur J Epidemiol 14: 555-561.

49. Inoue $\mathrm{G}$, Horiike $\mathrm{N}$, Michitaka $\mathrm{K}$, Onji M (2000) Hepatitis $\mathrm{C}$ virus clearance is prominent in women in an endemic area. J Gastroenterol Hepatol 15: 1054-1058.

50. Hayashi J, Kishihara Y, Ueno K, Yamaji K, Kawakami Y, et al. (1998) Agerelated response to interferon alfa treatment in women vs men with chronic hepatitis C virus infection. Arch Intern Med 158: 177-181.

51. Yamakawa Y, Sata M, Suzuki H, Noguchi S, Tanikawa K (1996) Higher elimination rate of hepatitis $\mathrm{C}$ virus among women. J Viral Hepat 3: 317-321.

52. Pourshams A, Khademi H, Malekshah AF, Islami F, Nouraei M, et al. (2010) Cohort Profile: The Golestan Cohort Study-a prospective study of oesophageal cancer in northern Iran. Int J Epidemiol 39: 52-59. 